The Philosophical Journal of Conflict and Violence

Vol. III, Issue 1/2019

(C) The Authors 2019

Available online at http://trivent-publishing.eu/

\title{
Violence, Integrity, Production. On Bataille's Restricted Economy
}

\author{
Andrea Rossi \\ Department of Philosophy, Koç University, \\ Turkey, arossi@ku.edu.tr
}

\begin{abstract}
Building and expanding on George Bataille's analysis of the restricted economy, the paper theorises violence as a plastic and productive force. Challenging accounts that, in different ways, define political violence solely as a negative and dis-integrating power (i.e. destructive of preexisting - actual or potential - "things"), the essay concentrates on the force that is unleashed to produce "unity" and "integrity", be it at the individual or at the collective level. This perspective, I suggest, might contribute to ganging the limits of the (potentially unbounded) violence needed by contemporary political and economic regimes to construe and secure their integrity.
\end{abstract}

Keywords: Bataille; Restricted Economy; Transcendental Violence; Production; Homogeneity; Heterogeneity; Integrity.

DOI: 10.22618/TP.PJCV.20193.1.192003

The PJCV Journal is published by Trivent Publishing

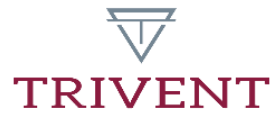

This is an Open Access article distributed in accordance with the Creative Commons Attribution Non Commercial (CC$B Y-N C-N D$ 4.0) license, which permits others to copy or share the article, provided original work is properly cited and that this is not done for commercial purposes. Users may not remix, transform, or build upon the material and may not distribute the modified material (bttp:/ / creativecommons.org/ licenses/by-nc/4.0/) 


\title{
Violence, Integrity, Production. On Bataille's Restricted Economy
}

\author{
Andrea Rossi \\ Department of Philosophy, Koç University, \\ Turkey, arossi@ku.edu.tr
}

\begin{abstract}
Building and expanding on George Bataille's analysis of the restricted economy, the paper theorises violence as a plastic and productive force. Challenging accounts that, in different ways, define political violence solely as a negative and dis-integrating power (i.e. destructive of preexisting - actual or potential - "things"), the essay concentrates on the force that is unleashed to produce "unity" and "integrity", be it at the individual or at the collective level. This perspective, I suggest, might contribute to ganging the limits of the (potentially unbounded) violence needed by contemporary political and economic regimes to construe and secure their integrity.
\end{abstract}

Keywords: Bataille; Restricted Economy; Transcendental Violence; Production; Homogeneity; Heterogeneity; Integrity.

"From elsewhere or beyond, violence brandishes another form, if not another meaning."

Jean-Luc Nancy

\section{Introduction}

This essay is a first attempt at exploring the question of violence - its perception, representation and circulation in contemporary societies - from the perspective of what might be called, in a seemingly paradoxical fashion, its plastic and productive qualities, or, in other words, its power to engender, organize, unify, integrate, order, etc. This analysis thus deliberately runs against common perceptions (as well as most philosophical interpretations) of violence which tend to associate the term to the ideas of destruction, loss, break, disintegration, etc., thus referring primarily to the negative force (vis) of violence or - which, in a way, amounts to the same - to the violence intrinsic to any violation (violatio). ${ }^{2}$ After all, that such interpretations have become hegemonic should come as no surprise, especially when considering the deepseated moral connotations that the concept has taken on in our culture, such that any talk of violence is almost invariably interpreted as a call to end violence or, in any case, to heal the wounds that it inflicts on an otherwise healthy and intact (physical, ethical or collective) body. In order to problematize these assumptions, the essay will ask, somehow counterintuitively, what kind of violence is implicated in the production of any such whole: a question whose consequences, as I will suggest, are not only philosophical, but touch in fact on one of the crucial predicaments of our political present.

\footnotetext{
${ }^{1}$ Jean-Luc Nancy, The Ground of the Image (New York: Fordham University Press, 2005), 16.

2 I am referring, of course, to the twofold etymology of the Latin violentia.
} 
To point to the productive quality of violence will entail, therefore, in the first instance, re-examining those theoretical perspectives that tend to reduce it to a purely negative "fact." Yet - to pre-empt any facile misunderstanding - I should stress how this is precisely not to glorify violence in the name of some higher value or biological necessity. Quite to the contrary, my preoccupation is with all that which any negative interpretation hides and leaves unquestioned and, a fortiori, with all the "useful" oppression that any such omission risks justifying. I am thinking, in particular, of how we are ordinarily enjoined to envision "the other of violence" (be it peace, politics, ethics, community, culture, society, etc.) as merely the opposite or the negation of violence's fundamental negativity, in a way that may naturally legitimize, in turn, the use of force (potentially ad infinitum) to protect unity and integrity from their dissolution.

The analysis of the systemic or structural violence that permeates contemporary societies and is reproduced by its institutional mechanisms has already attracted wide attention. ${ }^{3}$ Yet, as we shall see, the question that the literature generally focuses on is the violence that may accompany, more or less episodically, the enforcement of order, or, in other words, all that which may be violated, suppressed or excluded to preserve the unity and integrity of a social whole. Systemic violence would appear, in this respect, functional to the ordering of the political body (in as far as it would simply eliminate what threatens it), rather than, as it were, inherent to the act of ordering itself. The guiding hypothesis of this paper is, on the contrary, that political violence does not only act through separating friends from enemies, the inside from the outside, the potential from the actual etc., as though all it did was to create divisions within an already given - unitary and homogenous - sphere of reality. Rather, it also impresses (or, more precisely, it attempts to impress) on reality a form that is, in some sense, irreducible to the forces and the "things" on which it is exerted. It is this endeavour to transcend, ${ }^{4}$ rather than merely rearrange or reorganize, the "given" to define the plastic and productive qualities of violence, as well as the aggressions needed to secure the integrity of a political or individual body.

In order to foreground this set of questions, the essay will build and expand on George Bataille's work. Whilst the literature has extensively explored the connections between his understanding of violence and that of "limit-experiences" (the excess, the sacred, sacrifice, eroticism, mysticism, heterogeneity, the general economy etc.), I will call attention to a question that, as of yet, to my knowledge, has received far less attention: namely, the forms that violence may take in the realm of the restricted economy, that is, in the profane world of utility andproduction. To anticipate the main argument of the paper: if "limit-experiences," in Bataille, entail the destabilization of ordering structures (those, that is, securing the smooth functioning of the life-process of society), the genesis of these structures is itself implicated in a different, if more elemental and widespread, kind of "violation." As we shall see, the latter manifests itself in the reiterative production of things and persons, objects and subjects, thinghood and subjectivity - as that which creates and preserves the integrity and mutual incompatibility of the terms of each of these pairs.

\footnotetext{
3 Johan Galtung, "Violence, Peace, and Peace Research," Journal of Peace Research 6/3 (1969): 167-91; Johan Galtung, "A Structural Theory of Imperialism," Journal of Peace Research 8/2 (1971): 81-117; Johan Galtung, "Cultural Violence," Journal of Peace Research 27/3 (1990): 291-305; Yves Winter, "Violence and Visibility," New Political Science 34/2 (2012): 195-202; Kenneth A. Parsons, "Structural Violence and Power," Peace Review 19/ 2 (2007): 173-81; Joan Cocks, "The Violence of Structures and the Violence of Foundings," New Political Science 34/2 (2012): 221-27.

${ }^{4}$ See Zeynep Direk, "Immanent and Transcendent Violence in Bataille," Bulletin de La Société Américaine de Philosophie de Langue Française 14/2 (2004): 29-49.
} 
The argument will proceed as follows. In the next section, I will review debates on the definition of violence - and, more specifically, on "restricted" and "wide" interpretations so as to show how, in spite of their numerous differences, there would seem to be a widespread consensus that violence necessarily entails some violation of integrity. Through a close reading of George Bataille, the second section will then outline an alternative approach - one focusing instead on the positive correlations between violence, integrity and production. The last section will conclude with a few thoughts on the relevance of this line of inquiry to a critical appraisal of the present.

\section{Negative Violence}

To clarify what is at stake in the theorization of violence as a plastic and productive force, it will help first to contextualize the analysis within the wider academic debates on violence and on the respective virtues and limits of what have been termed "restricted" versus "wide" 5 "minimalist" versus "comprehensive," "observational" versus "expansive" - definitions. My aim, here, will be neither to take a stance within such debates nor to review them in detail. The argument will rather explore the conceptual frameworks that inform their different understandings of how violence emerges, marks and remodels the objects that it invests, so as to define more precisely, in the following sections, my take on the subject.

Broadly speaking, debates in this area revolve mainly on whether the word "violence" should refer exclusively to visible, actual and tangible episodes of aggression, injury and destruction (as in "restricted," "minimalist" and "observational" definitions) or whether it may accurately be employed to describe a broader set of phenomena - such as oppression, exploitation, systemic marginalization - whose effects, even when not entailing a direct physical or psychological abuse, may nevertheless be equally or even more harmful (as in "wide," "comprehensive" or "expansive" definitions).

Restricted definitions correspond, in a way, to the most intuitive connotations of the concept, as it is commonly employed in everyday speech. Their emphasis is on physical force that "injures, damages, violates or destroys people or things"8 or, as another author put it, on "positive interpersonal acts of force usually involving the infliction of physical injury." 9 Their aim, as it is easy to guess, is to delineate, as precisely as possible, the conceptual perimeter of violence by circumscribing the latter exclusively to actions that impair, weaken, diminish, damage, or even annihilate the physical integrity of persons and objects. These perspectives would therefore appear completely indifferent - deliberately so - to the plastic aspects of violence. As their focus rests primarily on actual "strikes" and their tangible and direct effects, they systematically ignore the broader socio-cultural frameworks out of which singular episodes of violence may originate. The confines of violence would coincide, as it were, with the "wounds" and the "void" that any offense leaves behind itself, on the "things" that it violates. Moreover, even when they incorporate psychological abuses within their definitions, this would not still seem to alter their fundamentally negative view, at least in as far moral suffering is simply presented as damage inflicted on some pre-existing psychic feature, or, put differently, as "mental harm." 10

\footnotetext{
${ }^{5}$ C. A. J. Coady, "The Idea of Violence," Journal of Applied Philosophy 3/1 (1986): 3-19.

${ }^{6}$ Vittorio Bufacchi, Violence and Social Justice (New York: Springer, 2007).

${ }^{7}$ Kenneth W. Grundy and Michael A. Weinstein, The Ideologies of Violence (Columbus: Merrill, 1974).

${ }^{8}$ Ted Honderich, After the Terror (Montreal: McGill-Queen's University Press, 2003), 91.

${ }^{9}$ C. A. J. Coady, "The Idea of Violence": 4.

${ }^{10}$ Robert L. Holmes, "Violence and Nonviolence," in Violence, ed. J. A. Shaffer (New York: David McKay Company, 1971), 112.
} 
By concentrating on the long-term effects of recursive forms of exclusion, discrimination and coercion, "wider," "comprehensive" or "expansive" definitions aim precisely to question the possibility of limiting violence to actions that impair, destroy or subtract something from an already existing "object." One of the most influential accounts in this area is, as is well known, Johan Galtung's theory of structural violence. ${ }^{11}$ One of his key insights is that, aside from its immediate and visible expressions, violence may be inscribed into, and propagate through, institutional frameworks that are responsible not only for an unequal distribution of resources and rights, but also for depriving certain individuals or groups of "the power to decide over the distribution of [such] resources." 12 Further, political and economic discrimination may be supported by cultural apparatuses that legitimise and condemn selectively the violence that is embedded in social structures and the one perpetrated by its victims, thus making knowledge itself into a means of oppression. ${ }^{13}$

If, to be sure, these observations might seem to add little to classical Marxist and postMarxist theories of exploitation, alienation and cultural hegemony, their interest lies, I believe, in the way they link the systemic dimension of violence to a specific and highly symptomatic understanding of subjectivity. The possibility of a wide definition rests, for Galtung, on the intuition that "[v]iolence is present when human beings are being influenced so that their actual somatic and mental realizations are below their potential realizations." ${ }^{14}$ Said otherwise, there is structural violence only where abuses do not only affect some particular moral or physical features of a subject but subjectivity itself, understood as an existential project aimed at the full actualization of the individual's potentialities. Violence penetrates institutions when harm is inflicted not only, as it were, on a life (or, at any rate, on some of its characters), but on a form of life as well: that is, when it hinders existence from achieving its legitimate form and from completing the project that it always already is.

Leaving aside the varied philosophical and definitional problems that this perspective may generate, ${ }^{15}$ for the sake of the present argument, I shall simply note how it somehow inverts one of the basic presuppositions of restricted definitions. Whereas the latter generally point to the capacity of violence of turning being into nothing, Galtung delineates an almost opposite logic, whereby nothing (or, in any case, that which is not yet, but could and should be, i.e. potentiality) might be prevented from coming into being. In this sense, there might be violence even when nothing real or actually existing is violated: even, that is, when "nothing" is lost, mutilated or destroyed.

This, to be sure, is a crucial observation, if only for the way it opens up the question of how violence may - and indeed regularly does - thwart man's open relation to time and selfhood. And yet, I would argue that Galtung's approach still falls short of acknowledging what I have termed the plastic and productive qualities of violence. That the latter might negate a potential, rather than an actual, existence still does not imply that it could "bring something new into the world". In fact, one might even suggest that, by translating it into the grammar of a metaphysic of subjectivity, Galtung further radicalized the negative conceptions supported by minimalist definitions. Violence, for him, is not only a destructive or unproductive force but, indeed, a counter-productive one as well, since it does not only violate an existing subject and its unity, but, in the first instance, the possibility of its emergence as a whole, complete

\footnotetext{
${ }^{11}$ Johan Galtung, "Violence, Peace, and Peace Research"; Johan Galtung, "A Structural Theory of Imperialism"; Johan Galtung, "Cultural Violence."

${ }^{12}$ Johan Galtung, "Violence, Peace, and Peace Research," 171 (emphasis added).

${ }^{13}$ Johan Galtung, "Cultural Violence."

14 Johan Galtung, "Violence, Peace, and Peace Research," 168.

${ }^{15}$ See Yves Winter, "Violence and Visibility;" Joan Cocks, "The Violence of Structures and the Violence of Foundings"; Kenneth A. Parsons, "Structural Violence and Power."
} 
entity. Production - the bringing-forth (pro-ducere) of the potential onto the actual - would thus appear as the absolute "other" of violence, according to a widely accepted scheme which simply (and, perhaps, over-simplistically) sees creation and terror as irreconcilable forces. ${ }^{16}$

In this respect, Bufacchi's observation that both "minimalist" and "comprehensive" definitions ultimately rest on a common understanding of violence as violation of integrity seems fundamentally correct. ${ }^{17}$ Without denying their differences - nor, for that matter, that violence is also invariably destructive - both approaches appear unable to think through the violence that underlies the production of integrity and unity (whether actual or potential), which they regard, in fact, as the given and unproblematic "other" of violence. Through an exegesis of George Bataille's work, the following section will attempt precisely - if only tentatively - to challenge this assumption.

\section{Eating: On Transcendence}

The academic literature has already extensively examined the connections between Bataille's understanding of violence and the set of questions that he addressed in his theory of sovereignty, the excess, the general economy, the inner experience, transgression, heterogeneity, etc. ${ }^{18}$ As different authors have stressed, the violence Bataille was interested in was first and foremost the one underlying "limit-experiences"19: sacrifice, ecstasy, laughter, madness, art, eroticism, death, etc. ${ }^{20}$ To use the terminology Bataille employed in an early essay, ${ }^{21}$ these experiences are violent to the extent that they disrupt and tear apart social homogeneity, i.e. the domain of production, utility, law, commensurability, equality, measure, etc., which presides over the everyday government of society - what Bataille will later refer to, in The Accursed

${ }^{16}$ See, for example, the view of important authors such as John Dewey and Richard Bernstein: "energy becomes violence when it defeats or frustrates purposes instead of executing or realizing it. When the dynamite charge blows up human beings instead of rocks, when its outcome is waste instead of production, destruction instead of construction, we call it not energy or power but violence" (Dewey, quoted in Vittorio Bufacchi, Violence and Social Justice, 19); "[v]iolence is not creative; it is essentially destructive" Richard J. Bernstein, Violence: Thinking without Banisters (John Wiley \& Sons, 2018), 19.

${ }^{17}$ Bufacchi, who also supports this perspective, proposes the following definition: "An act of violence occurs when the integrity or unity of a subject (person or animal) or object (property) is being intentionally or unintentionally violated, as a result of an action or an omission. The violation may occur at the physical or psychological level, through physical or psychological means. A violation of integrity will usually result in the subject being harmed or injured, or the object being destroyed or damaged." Vittorio Bufacchi, Violence and Social Justice, 43-44.

18 See, for example, Tiina Arppe, "Sacred Violence: Girard, Bataille and the Vicissitudes of Human Desire," Distinktion: Journal of Social Theory 10/2 (2009): 31-58; Michel Feher, Conjurations de la Violence: Introduction à la Lecture de Georges Bataille (Paris: PUF, 1981); H. Janse van Rensburg, "Georges Bataille's Interpretation of Nietzsche: The Question of Violence in Surrealist Art," South African Journal of Cultural History 3/4 (1989): 388-98; Stephen Bush, "Sovereignty and Cruelty: Self-Affirmation, Self-Dissolution, and the Bataillean Subject," in Negative Ecstasies: Georges Bataille and the Study of Religion, ed. Jeremy Biles and Kent L. Brintnall (New York: Fordham University Press, 2015), 38-50.

${ }^{19}$ See Michel Foucault, Power: The Essential Works of Michel Foucault 1954-1984, Vol. 3, ed. James D. Faubion, 3 edition (London: Penguin, 2002), 241.

${ }^{20}$ See, Georges Bataille, The Accursed Share: Volume I (New York: Zone Books, 1991); Georges Bataille, Erotism: Death and Sensuality, (San Francisco: City Lights Publishers, 1986); Georges Bataille, The Accursed Share: Volumes II \& III (New York: Zone Books, 1993); Georges Bataille, Inner Experience (Albany: State University of New York Press, 2014); Georges Bataille, Theory of Religion (New York: MIT Press, 1992); Georges Bataille, "The Notion of Expenditure," in The Bataille Reader, ed. Scott Wilson and Fred Botting (Oxford: John Wiley \& Sons, 1997), 167-81; Georges Bataille, "The Psychological Structure of Fascism," New German Critique 16 (1979): 64-87.

${ }^{21}$ Georges Bataille, "The Psychological Structure of Fascism." 
Share, as the "restricted economy." 22 Limit-experiences (just like, as we shall see, animal violence) pertain to the realm of the heterogeneous, the inassimilable, the base, the unfitting.

Bataille's understanding of violence is therefore deliberately idiosyncratic. If, on the one hand, it refers to forces that negate the integrity, coherence and stability of cultural and social frameworks (thus conforming, in a way, to standard definitions of violence), such forces do not directly attack or destroy that which they negate, but only resist its "logic of adsorption" - since the "very term heterogeneous indicates that it concerns elements that are impossible to assimilate" and that, precisely because of that, have "the force of a shock." 23 It is the irreducibility of limit-experiences to all social schematizations to make them a threat to the world of utility, order and production - such that the heterogeneous would appear as the least acceptable form of violence within the confines of the homogeneous. ${ }^{24}$

While I will return to the implications of this specific conception of violence in the conclusion to the essay, this - it should be clear - could hardly be described as a productive form of violence, i.e. vis capable of synthesizing, unifying, integrating, ordering, etc. Whilst this is not either a purely destructive or "blind" force - how, after all, could one portray art, eroticism, laughter this way? - it still exceeds, by definition, rationalities of production, as the world of heterogeneity (the general economy, the excess, transgression) is indissolubly linked, in Bataille, to forms of "unproductive expenditure." 25

To investigate the plastic and creative qualities of violence, we shall therefore focus on a different line of inquiry within Bataille's oeuvre: i.e. the one revolving around the violence that permeates the world of the restricted economy; the realm of the profane; the world of utility, conservation, security, order, growth, etc. ${ }^{26}$ Violence is at its most productive - in a sense that will hopefully soon become clearer - precisely within these spheres, as the centripetal force that holds them together, individually as well as collectively.

Zynep Direk - one of the few authors who has grappled with this question - has aptly defined this violence transcendental, to differentiate it from both natural aggressiveness and the ecstatic energies unleashed by limit-experiences - both of which reflect instead, in different ways, the overflowing logic of the general economy, or what she proposes to call "intimate violence." 27 The transcendental dimension of these forces lies in their striving to "rise above" the dynamics of offence, combat and hostility that are at play in the animal world. The realm of utility, technicity, science and economy in the restricted sense - all that which, broadly speaking, is implicated in the "metabolism between [man] and nature," according to Marx's formulation ${ }^{28}$ - is founded upon - and simultaneously deploys - a kind of violence irreducible to the one that suffuses animal life. Homo faber - and even more so animal laborans - do not only have at their disposal incalculably more powerful means of appropriating and exploiting their surroundings than any other living being does. The violence that they direct at the world is of a formally different quality too.

Yet, whereas this violence is without a doubt sui generis, it still bears an essential relation to the one that permeates the rest of the living world. Put differently, the restricted economy

\footnotetext{
${ }^{22}$ Georges Bataille, The Accursed Share Vol I.

${ }^{23}$ Georges Bataille, "The Psychological Structure of Fascism," 67, 70.

${ }^{24}$ See Georges Bataille, Theory of Religion, 46-47:"The real order does not so much reject the negation of life that is death, as it rejects the affirmation of intimate life, whose measureless violence is a danger to the stability of things."

${ }^{25}$ Georges Bataille, The Accursed Share Vol I, 137.

${ }^{26}$ For an influential reading of the relation between the general and the restricted economy in Bataille, see Jacques Derrida, "From Restricted to General Economy: A Hegelianism without Reserve," in Writing and Difference (New York: Routledge, 2001), 317-50.

${ }^{27}$ Zynep Direk, "Immanent and Transcendent Violence in Bataille."

${ }^{28}$ Karl Marx, Capital. Volume I (London: Lawrence \& Wishart Ltd, 1996), 187.
} 
does and could not negate absolutely the "excess" that is at play in the spheres of the heterogeneous and the general economy, as the latter - as its very name suggests - refers to an economy that presides over the whole of being and therefore also over any "narrower" human affair. ${ }^{29}$ To appreciate how violence in the world of utility could become productive, we should therefore look at the way in which it may remodel and give a new form to - without yet completely altering or escaping - the logic of non-human violence. ${ }^{30}$

Bataille developed this argument most systematically in his poetic analysis of eating, which he presented as one of the main spring of violence, appropriation, use, capture and slaughter of both living and non-living beings. ${ }^{31}$ Whilst, from an individual perspective, eating may manifest itself as mere need, it is important to stress how, from the point of view of the overall dynamic it generates, it instantiates instead the general economy's excessive tendency to consumption, destruction and squandering of matter and energies without a final purpose (assuming, to be sure, as Bataille did, that nature knows no teleology): "[t] he eating of one species by another is the simplest form of luxury." 32 The question of the specific shape that violence takes in the world of production may therefore be tackled through examining the distinctive way man makes use of such luxury, that is, how man eats and where eating places him vis-à-vis the "things" that he eats - starting from an analysis of the immeasurable distance between his and the way all other living beings consume.

The lion is not the king of the beasts. In the movement of the waters he is only a higher wave overturning the other, weaker ones. That one animal eats another scarcely alter a fundamental situation: every animal is in the world like water in water. ${ }^{33}$

For Bataille animal violence may be said to reflect three basic principles. ${ }^{34}$ First, it could never alter essentially the situation in which it happens to take place or the order of things that occasioned it. That, in spite of annihilating it, the predator continues to live in the same milieu as its prey - "like water in water" - entails, in the first place, its inability to produce anything new, be it in the form of social structures or subject-positions. In fact - second - animal consumption responds to what might be called a logic of non-identification, since it is never exerted by a subject upon another, but it only arises out of the temporary crystallization of an open play of forces ("a higher wave overturning the other, weaker ones" ${ }^{35}$ ), which, as such, does not create any partitions or differential unities. Natural violence does not "break." In a way, in fact, it binds together - if only for the brief moment of its striking - the "atoms" which it brings into collision, in what might be defined as a movement of mutual in-differentiation:

What is given when one animal eats another is always the fellow creature of the one that eats. It is in this sense that I speak of immanence. I do mean a fellow creature perceived as such, but there is no transcendence between the eater an the eaten;

\footnotetext{
${ }^{29}$ Georges Bataille, “The Notion of Expenditure”; Georges Bataille, The Accursed Share Vol I.

30 As Jacques Derrida ("From Restricted to General Economy: A Hegelianism without Reserve," 319) suggested, the excess (the general economy) around which Bataille's discourse revolves is not simply negation of order and utility (the restricted economy), as it in fact "exceeds the oppositions of concepts" and dialectical negations, which only appear from within the horizon of the restricted economy.

31 See Georges Bataille, Theory of Religion, Chapters I and II especially.

32 Georges Bataille, The Accursed Share Vol I, 33.

33 Georges Bataille, Theory of Religion, 18-19 emphasis in the original.

34 Principles which, to be sure, as Bataille was well aware of, could not be expressed in the language of clear knowledge and scientific objectivity, but only, at best, poetically. Ibid., 21.

35 Or, as Bataille put it elsewhere: "In the general effervescence of life, the tiger is a point of extreme incandescence." Georges Bataille, The Accursed Share, 1991, 33.
} 
there is a difference, of course, but this animal that eats the other cannot confront it in an affirmation of that difference. ${ }^{36}$

Hence - third - consumption, in its natural form, does not hierarchize or order politically the forces that it brings into play. The predator does not dominate - as a master (dominus) does a slave - its prey. "The lion is not the king of the beasts." As Nietzsche had already understood, as against the age-old theology of the chain of being, ${ }^{37}$ "in nature...there is nobody who commands, nobody who obeys, nobody who trespasses." 38 Beasts exist within a field of shared immanence, even when struggling for life and death: "between the animal that is eaten and the one that eats, there is no relation of subordination.' 39

Un-productivity, non-identification, non-domination: human violence in the restricted economy that is, within the sphere of human production, and as exemplified, in particular, by our styles of alimentation - might be said to arise in opposition to these three "general principles." Note how, as mentioned above, this is still not to imply that the restricted economy could silence or suppress the general economy, since, for Bataille, the latter is, in a way, unsurpassable. It is instead the tension towards the overcoming of the three principles above to give human consumption its characteristic form. It is the recursive attempt to make it into a means of production, identification and domination - and, therefore, to inscribe into it a matrix of "situational differences" to define the restricted economy.

At the basis of this mechanism lies precisely the transcending nature of human violence mentioned above. ${ }^{41}$ Opposing the "intimate" communication that normally flows through the animal that eats and the one that is eaten, consumption, in man, establishes a separation between the consumer and what he consumes, such that

[a]t least in normal circumstances, man is an animal that does not have a part in that which he eats... Concerning that which I kill, which I cut up, which I cook, I implicitly affirm that that has never been anything but a thing. ${ }^{42}$

Thanks to the whole gamut of techniques that man is able to apply to his foodstuffs, the latter are made to withdraw from the circuits of intimate appropriation, thus appearing from "a viewpoint from which the immanent elements are perceived from the outside as objects" 43 - i.e. as things standing-against (Gegenstand) the animal consuming them. The distance introduced by the tool is not, in this sense, merely a spatiotemporal one, but it consists of an ontological rift as well: a separation, within the fabric of being, between subjects and objects, as "[ $\mathrm{t}]$ he developed tool is the nascent form of the non-I." 44 Man, hence, is precisely not what he eats (or, at least, such he appears to bimself): he is the animal who transcends what it consumes or, indeed, the animal for whom eating is also, at the same time, a means to (self-)transcendence.

It should be easy to see, at this point, in what respect - within the compass of the restricted economy - violence would serve to subjectify and subjugate, and accordingly to suspend the

${ }^{36}$ Georges Bataille, Theory of Religion, 17.

${ }^{37}$ See Arthur O. Lovejoy, The Great Chain of Being: A Study of the History of an Idea, New Ed edition (Cambridge, Mass.: Harvard University Press, 1976).

${ }^{38}$ Friedrich Nietzsche, The Gay Science (Cambridge, U.K.: Cambridge University Press, 2001), 168.

${ }^{39}$ Georges Bataille, Theory of Religion, 18. As against, for example, the human struggle for recognition, as envisioned by Hegel. See Georges Bataille, "Hegel, l'Homme et l'Histoire," in CEuvres Complètes, Vol XII (Paris: Gallimard, 1956), 349-69; Georges Bataille, "Hegel, Death and Sacrifice," Yale French Studies 78 (1990): 9-28.

40 Zynep Direk, "Immanent and Transcendent Violence in Bataille," 36.

${ }^{41}$ See Zynep Direk, "Immanent and Transcendent Violence in Bataille."

${ }^{42}$ Georges Bataille, Theory of Religion, 39.

43 Ibid., 31.

${ }^{44}$ Ibid, 27. 
principles of non-identification and non-domination which preside over animal consumption. Transcendental violence simultaneously isolates and elevates the subject above what is susceptible of becoming and being consumed as a mere object. ${ }^{45}$ The intimacy that connects the prey to the predator as "fellow creatures" is this way covered up by a distance that forecloses any contact and intermingling. The open field of forces in which animals are immersed crystallizes, in addition, in a well-defined hierarchy: man is the king of beast, in a way that no other animal has or could ever have been, regardless of their strength or place in the food chain.

Even though Bataille never framed it in these terms, I would argue that the whole question of integrity discussed in section I (concerning the definition of individuals or groups as selfsufficient, unitary wholes) is but a surface effect of the form that consumption takes for homo laborans. We should note, in this sense, how the etymology of the word still resonates - in ways that may not be immediately audible, yet essentially - with the concept of integrity. The latter has its roots in the Latin in-tangere (literally: "non-touch") - a term that indicates the condition of being untainted, pristine, unsullied, immaculate, pure, etc. and which is therefore intimately allied to the spheres of religion and the sacred. ${ }^{46}$ The meaning of wholeness, entirety and completeness would in this sense appear derivative with respect to the moral connotations of the term, as they still transpire, for example, in the sense of integrity as uprightness, probity, honesty, rectitude, etc. To have integrity is to be intact (also: un-touched, intactus): to be sheltered from contacts with the heterogeneous (the sullied, the impure, evil, the profane), as though the unity and completeness which the word also evokes - and which comes to the fore in the definitions of violence reviewed above - was somehow conditional on a non-relation with, and immunity from, one's "outside." Following through this line of reasoning, to preserve the integrity of something or someone would not be, in the first place, to secure their unity (whether actual or potential) but, rather, to produce their identity through positing - and simultaneously enforcing - the absolute heterogeneity between two "segments" of reality.

Yet is not this exactly the mechanism that, as seen, makes human consumption possible? Is not the positing of "interruptions in the indistinct continuity" 47 the primary operation of the restricted economy and the basis for the production of discrete unties - what philosophy will at some point call substances, bypokeimena, subjects? How, after all, could we ever have conceived of integrity without first having exited the "water," the continuum of being, in which animals are still submerged? But then - if we recall how at stake here is not only a conceptual apparatus but the concrete upshot of man's way of using, appropriating, consuming and eating his "other" - could we not speculate that any endeavour to construe and defend integrities (of persons, souls, communities, objects, etc.) would somehow be entangled, as its effect and necessary condition, to the transcendental violence at play in the restricted economy? ${ }^{48}$

If it is true that man can only eat objects (that is to say, entities that cannot penetrate the boundaries of his subjectivity), any endeavour to compose or recompose his integrity might

45 Including also, to be sure, the human body. See ibid, 38.

${ }^{46}$ The relation between the sacred and human consumption is in fact a central theme of Georges Bataille's Theory of Religion. On the spatial and psychological separation between the sacred and the profane as the condition of possibility of the experience of the religious, see Mircea Eliade, The Sacred and the Profane: The Nature of Religion (Boston: Houghton Mifflin Harcourt, 1959).

${ }^{47}$ Georges Bataille, Theory of Religion, 27.

48 The analysis, at this point, may intersect - without yet overlapping - the deconstructionist critique of the metaphysics of presence and subjectivity: "But the unity of the thing, of presence and of the subject is itself violent... unity must thus relate itself to itself in itself in order to present itself and thus externalize itself, while also excluding from itself that which it is not and ought not to be, that of which it is the refusal and the violent reduction." Jean-Luc Nancy, The Ground of the Image, 23 (emphasis in the original). 
be regarded as a necessary condition for transforming reality into an "edible good" - a thing, that is, that could be taken, processed and subdued without having to be "touched" and, therefore, surreptitiously, without having to be violated or abused, since the object of buman consumption is a being that may be eaten without it eating away at the integrity of the subject.

It is from within this horizon that human violence, I want to argue, reveals its distinctively plastic powers. If animal aggressiveness is in any case unproductive (as it could only alter a given diagram of forces, without yet ever departing from their immanence), transcendental violence, even before manufacturing any new "thing," invariably tends to produce a new world: a world of "integrities," "incompatibilities," "situational differences" and "things" - a world, that is, in which "water ought never to touch water." This, in a way, is indispensable for man to consume his world: he must first transform it into "thinghood," i.e. into "a world, a plane on which it is possible to situate clearly and distinctly, at least so it appears, that which in theory cannot be known in the same way." 49 This primitive objectivation is, in turn, the ground of any subsequent, specific act and art of production. The paradox here lies in that, to preserve himself "untouched" from his objects, the violence with which man "touches" bis world must at the same time create a world susceptible of being infinitely objectified. After all, what is production but the endlessly reiterable strife to withdraw and isolate discrete elements - man in primis - from within the continuity of being, and thus to guard their integrity, for as long as possible, from the pressure of the heterogeneous? 50

\section{Ends of Production}

Examining violence at this apparently overly abstract level might beg the question of how this study could contribute to a critique of the "real violence" that tears apart, destroys and subdues in this world. Analysing the ways in which violence (or rather, that specific form of violence which, following Direk, I have called transcendental) is implicated in the production of "situational differences," "thinghood" and "integrities" might seem far removed from any practical concern for the terror that - whether individually or systemically, physically or psychologically - hover over our lives in absolutely concrete ways. Why, then, resuscitate some eccentric perspective on the productivity of violence, at a time, especially, in which the fear of humanity's (self-)annihilation seem so much more worrying? Why attempt to uncover some seemingly universal truth about the way man objectifies and uses his world, when the latter might already be doomed to extinction? In any case, what would we gain from learning that some of our most prized values - integrity, unity, wholeness, production - are but the accretion of some immemorial or forgotten abuse? Would not pretending that violence is everywhere, after all, leave us exactly as indifferent as if we completely ignored its existence?

Without pretence of even beginning answering these questions, in this section, and in lieu of a conclusion, I would nevertheless like to put forward some preliminary thoughts concerning the relevance of the present analysis to a critical discourse on the present.

Before anything else, it will be worth recalling how the aim of this paper was not to expose hidden forms of epistemic, discursive, conceptual or metaphorical violence. When talking about the production of thinghood and integrity as the defining traits of transcendental violence, this was not to suggest - as it should hopefully be clear - that these categories simply witness to language's unduly simplification and deformation of reality. At stake has never been some alleged fault in the way we represent the world. Quite differently, I have tried to

\footnotetext{
${ }^{49}$ Georges Bataille, Theory of Religion, 30.

${ }^{50}$ See Max Horkheimer, Critical Theory: Selected Essays (London: Continuum: 1972), 198: “The determinative, ordering, unifying function is the sole foundation for all else, and towards it all human effort is directed. Production is production of unity, and production is itself the product."
} 
illustrate how and to what extent any "representation of integrity" is already part and parcel of the peculiar way man consumes, materially, his world. Creating or securing the integrity of individuals or groups are not merely ideological operations (whose effects, that is, could be circumscribed within the sphere of thought), but actions that concretely refashion the world and the way we inhabit it. The very same violence that in the animal kingdom remains immanent to the world in which it arises becomes, in the hands of man, a plastic force - one, that is, capable of turning its world into an aggregate of "edible objects," while keeping them at an essential distance from man's subjectivity. Economic production is, in this sense, but the most immediate, concrete and paradigmatic expression of this metamorphosis.

Undoubtedly, even allowing that this is the case, the question would still remain of how to reckon, ethically and politically, with this apparently universal anthropological - and anthropogenic - mechanism. If, after all, the constitution of subjectivity and objectivity as such is at stake, it might be tempting to interpret the argument as a moral indictment of civilization as a whole, if only because of its permanent transgressing of the natural (pre-subjective and pre-objective) order of things. Any such conclusion, however, would have to rest on a number of assumptions about the morality, or lack thereof, of nature and artifice, immanence and transcendence, which - besides being questionable in themselves - could only be defined, as anticipated, from within the order of political and moral rankings set up by the restricted economy. ${ }^{51}$ When considered from this perspective, the question of how to define and limit the violence that the latter unleashes would therefore structurally be foreclosed, as it would remain caught within the horizon of meanings and possibilities made available by the restricted economy itself.

As it should have already become apparent, this, however, has been precisely one of the central questions of the essay: its preoccupation was not to pass judgement on the way man consumes, appropriates and destroys its world and the objects within it, but - somehow less ambitiously - to point to the possible limits and perils of that unique mode of consuming, appropriating and destroying. Said otherwise, the question was not whether transcendental violence, along with the differences and unities that it produces, is morally faulted in itself, but rather, whether we could still afford ignoring its permanent risk of degenerating into a selfdestructive, auto-immune mechanism. ${ }^{52}$

This is, I believe, the point at which the foregoing analysis could prove especially useful for a critical reading of our political present. In spite of the endless talks about post-modernity's rejection of humanistic and positivistic modes of thought, our societies still appear captivated by the hope that a certain state of integrity, unity or harmony - whatever specific form it may take - could be produced, restored or defended from the centrifugal forces that permanently (and especially today) risk tearing it apart. I am thinking, for instance, of the many different strands of ecological thought that tend to project onto nature, often in an uncritical manner, a certain image of purity and intactness as a promise of salvation. ${ }^{53}$ But, in fact, the same issue transpires in all those political, social and economic projects (perhaps too many to even begin mentioning them), which, even when criticizing the world of utility, profits and capital, often seem incapable of reflecting self-critically on the destructive effects that any

\footnotetext{
51 Since, as seen (section III), it would be inappropriate to ascribe any order or hierarchy of values to the realm of the general economy. See also fn. 57.

52 On the notion of immunity and auto-immunity, see Roberto Esposito, Immunitas: The Protection and Negation of Life (Cambridge: Polity Press, 2011).

53 For critical perspectives on the environmental crisis inspired by Georges Bataille, see Allan Stoekl, Bataille's Peak: Energy, Religion, and Postsustainability (Minneapolis: University Of Minnesota Press, 2007); Andrea Rossi, "The Finitude of the World: Economy and Ecology," Theory \& Event 21, no. 4 (2018): 776-803.
} 
construction of integrity - including, perhaps, the ones they strive for - may entail. Needless to say, capitalism - especially in its neoliberal forms - is and remains paradigmatic of this tendency. ${ }^{54}$

To repeat it once again, the issue is not that order, integrity and production should be banned from our political vocabulary. The question rather concerns how, from within the horizon of the restricted economy, "the good" - as Bataille put it - could only appear as "an exclusion of violence," 55 and how this, in turn, might uncritically lead to justifying the violence required to achieve such an "exclusion." As the recent history of global liberalism - just like, in different ways, the neo-nationalistic tendencies that are spreading globally at the time of writing - continue to demonstrate, some of the most destructive impulses of political modernity originates precisely out of its inability to set limits to its need for security, unity, production and integrity. ${ }^{56} \mathrm{It}$ is in this sense that the theoretical perspectives reviewed in section I also appear irremediably partial: not, to be sure, because their concern with the negative effects of violence is misplaced or illegitimate, but rather because - by suggesting that violence is only negation of integrity or unity - they are bound (if only by omission) to efface the question of transcendental violence's potential unboundedness. ${ }^{57}$

As I have tried to demonstrate - and in spite of its alleged excesses - Bataille's philosophy might be read as a sustained reflection on the possible abuses and the necessary limits of the ordering and productive force of human violence. If the restricted economy is, by its own nature, unable to view and recognize the violence that permeates it (as its field of intervention only appears an ensemble of objects that can infinitely be consumed in so far as they are not subjects), it is only from the "estranged" perspective of the heterogeneous and the general economy that, perhaps, its limited ends could be reckoned with "objectively." 58 The issue, after all, has never been that man has turned violence into a plastic force, but rather that he has turned the latter into an "end in itself" 59 - into a form of life, that is, incapable of letting itself be consumed by the universal "holocaust" of life:

We can ignore or forget the fact that the ground we live on is little other than a field of multiple destructions. Our ignorance only has this incontestable effect: It causes us to undergo what we could bring about in our own way, if we understood. It deprives us of the choice of an exudation that might suit us. Above all, it consigns men and their works to catastrophic destructions. For if we do not

\footnotetext{
54 As I have argued in another essay, neoliberal economies do not simply conceal or ignore their destructive potential, but somehow portray it as the ultimate spring of profits and innovation - as exemplified, for instance, by Schumpeter's fanatic interpretation of "creative destruction." See Andrea Rossi, "Neoliberal Souls," Cogito 91 (2018): 121-53.

55 Georges Bataille, Theory of Religion, 80.

56 See Michael Dillon and Julian Reid, The Liberal Way of War. Killing to Make Life Live (New York: Routledge, 2009).

57 Bataille elaborated on this point especially in his numerous remarks on modern war, which he regarded as the incarnation of ancient economies of the sacred, now put to the service of an unbounded "rational calculation of effectiveness," in which "[t] he expenditure of forces continues, but it is subjected to a principle of maximum yield: if the forces are spent, it is with a view to the acquisition of greater forces." Georges Bataille, Theory of Religion, 66; see also Bataille, Erotism, 76-80; Bataille, The Accursed Share: Volume 1, 169-90. Roger Caillois, co-founder with Bataille of the Collège de Sociologie, developed a similar argument in Man and the Sacred (Urbana: University of Illinois Press, 2001), 163-80, and in Bellone ou la Pente de la Guerre (Paris: Flammarion, 2012).

58 Georges Bataille, "The Notion of Expenditure," 180: "if, finally, one demonstrates that this movement is impossible to contain or direct toward a limited end, it becomes possible, having abandoned all reserves, to assign a relative value to utility."

${ }^{59}$ See Elettra Stimilli, The Debt of the Living: Ascesis and Capitalism (Albany: SUNY Press, 2018).
} 
have the force to destroy the surplus energy ourselves, it cannot be used, and, like an unbroken animal that cannot be trained, it is this energy that destroys us; it is we who pay the price of the inevitable explosion. ${ }^{60}$

\section{References}

Arppe, Tiina. "Sacred Violence: Girard, Bataille and the Vicissitudes of Human Desire." Distinktion: Journal of Social Theory 10/2 (2009): 31-58.

Bataille, Georges. Erotism: Death and Sensuality. San Francisco: City Lights Publishers, 1986. "Hegel, Death and Sacrifice." Yale French Studies 78 (1990): 9-28.

. "Hegel, l'Homme et l'Histoire." In CEuvres Complètes, Vol XII, 349-69. Paris:

Gallimard, 1956.

. Inner Experience. Albany: State University of New York Press, 2014.

The Accursed Share: Volume I. New York: Zone Books, 1991.

The Accursed Share: Volumes II \& III. New York: Zone Books, 1993.

"The Notion of Expenditure." In The Bataille Reader, edited by Scott Wilson and

Fred Botting, 167-81. Oxford: John Wiley \& Sons, 1997.

. Theory of Religion. New York: MIT Press, 1992.

."The Psychological Structure of Fascism.” New German Critique 16 (1979): 64-87.

Bernstein, Richard J. Violence: Thinking without Banisters. Oxford: John Wiley \& Sons, 2018.

Bufacchi, Vittorio. Violence and Social Justice. New York: Springer, 2007.

Bush, Stephen. "Sovereignty and Cruelty: Self-Affirmation, Self-Dissolution, and the Bataillean Subject." In Negative Ecstasies: Georges Bataille and the Study of Religion, edited by Jeremy Biles and Kent L. Brintnall, 38-50. New York: Fordham University Press, 2015.

Caillois, Roger. Man and the Sacred. Urbana: University of Illinois Press, 2001.

Caillois, Roger. Bellone ou la Pente de la Guerre. Paris: Flammarion, 2012.

Coady, C. A. J. “The Idea of Violence.” Journal of Applied Philosopby 3/1 (1986): 3-19.

Cocks, Joan. "The Violence of Structures and the Violence of Foundings." New Political Science 34/2 (2012): 221-27.

Derrida, Jacques. "From Restricted to General Economy: A Hegelianism without Reserve." In Writing and Difference, 317-50. New York: Routledge, 2001.

Dillon, Michael, and Julian Reid. The Liberal Way of War. Killing to Make Life Live. New York: Routledge, 2009.

Direk, Zeynep. "Immanent and Transcendent Violence in Bataille." Bulletin de La Société Américaine de Pbilosopbie de Langue Française 14/2 (2004): 29-49.

Eliade, Mircea. The Sacred and the Profane: The Nature of Religion. Boston: Houghton Mifflin Harcourt, 1959.

Esposito, Roberto. Immunitas: The Protection and Negation of Life. Cambridge: Polity Press, 2011.

Feher, Michel. Conjurations de la Violence: Introduction à la Lecture de Georges Bataille. Paris: PUF, 1981.

Foucault, Michel. Power: The Essential Works of Michel Foucault 1954-1984, Vol. 3. London: Penguin, 2002.

Galtung, Johan. “A Structural Theory of Imperialism.” Journal of Peace Research 8/2 (1971): 81-117.

"Cultural Violence." Journal of Peace Research 27, no. 3 (1990): 291-305.

"Violence, Peace, and Peace Research." Journal of Peace Research 6/3 (1969): 167-91.

Grundy, Kenneth W., and Michael A. Weinstein. The Ideologies of Violence. Columbus: Merrill, 1974.

${ }^{60}$ Georges Bataille, The Accursed Share Vol I, 23-24. 
Holmes, Robert L. "Violence and Nonviolence." In Violence, edited by J. A. Shaffer, 101-35. New York: David McKay Company, 1971.

Honderich, Ted. After the Terror. Montreal: McGill-Queen's University Press, 2003.

Horkheimer, Max. Critical Theory: Selected Essays. New York: Continuum, 1972.

Lovejoy, Arthur O. The Great Chain of Being: A Study of the History of an Idea. Cambridge, Mass.: Harvard University Press, 1976.

Marx, Karl. Capital. Volume I (Karl Marx/Frederick Engels. Collected Works, Vol. 35). London: Lawrence \& Wishart Ltd, 1996.

Nancy, Jean-Luc. The Ground of the Image. New York: Fordham University Press, 2005.

Nietzsche, Friedrich. The Gay Science. Cambridge: Cambridge University Press, 2001.

Parsons, Kenneth A. “Structural Violence and Power.” Peace Review 19/2 (2007): 173-81.

Rensburg, H. Janse van. “Georges Bataille's Interpretation of Nietzsche: The Question of Violence in Surrealist art." South African Journal of Cultural History 3/4 (1989): 388-98.

Rossi, Andrea. "Neoliberal Souls." Cogito 91 (2018): 121-53.

. "The Finitude of the World: Economy and Ecology." Theory \& Event 21/4 (2018): 776-803.

Stimilli, Elettra. The Debt of the Living: Ascesis and Capitalism. Albany: SUNY Press, 2018.

Stoekl, Allan. Bataille's Peak: Energy, Religion, and Postsustainability. Minneapolis: University Of Minnesota Press, 2007.

Winter, Yves. "Violence and Visibility." New Political Science 34/2 (2012): 195-202. 